anales de psicología, 2018, vol. 34, nº 2 (may), 305-313 http://dx.doi.org/10.6018/analesps.34.2.294551
(C) Copyright 2018: Editum. Servicio de Publicaciones de la Universidad de Murcia. Murcia (Spain) ISSN print edition: 0212-9728. ISSN web edition (http://revistas.um.es/analesps): 1695-2294

\title{
Adaptation of the Five-Facet Mindfulness Questionnaire-Short Form (FFMQ-SF) to Spanish Family Caregivers of People with Intellectual and Developmental Disabilities
}

\author{
Lucía Oñate*, and Esther Calvete
}

Department of Personality, Assesment and Psychological Treatment. University of Deusto (Spain).

\begin{abstract}
Título: Adaptación del Cuestionario de las Cinco Facetas del Mindfulnes - Versión Reducida (FFMQ-SF) en una muestra española de Familiares Cuidadores de Personas con Discapacidad Intelectual y del Desarrollo.

Resumen: En los últimos años la intervención centrada en mindfulness ha cobrado atención en el área de los familiares de personas con discapacidad intelectual y del desarrollo (PDID). Además, el rasgo mindfulness ha sido relacionado con mayor bienestar, menores niveles de ansiedad y depresión y mejor calidad de vida en este colectivo. Por ello, disponer de herramientas que evalúen mindfulness en este grupo es relevante. El objetivo de este estudio fue la validación del Five Facets Mindfulness Questionnaire -Shor Form (FFMQ-SF; Bohlmeijer, Ten Klooster, Fledderus, Veehof y Baer, 2011) en una muestra española de cuidadores. Doscientos sesenta y cinco familiares de PDID (84.5\% mujeres y $15.5 \%$ hombres) con edades comprendidas entre 18 y 80 años participaron en esta investigación, completando el FFMQ-SF junto con medidas de malestar psicológico y calidad de vida. Los resultados confirmaron la estructura factorial del FFMQ-SF consistente en cinco facetas (Observar, Describir, Actuar consciente, No reaccionar y No juzgar) y mostraron consistencia interna adecuada. Se observaron relaciones significativas entre la mayoría de las facetas de mindfulness y menor malestar psicológico así como mejor calidad de vida. Los resultados sugieren que el FFMQ-SF puede ser utilizado adecuadamente con familiares de PDID.

Palabras clave: Rasgo mindfulness; Cuidadores; Discapacidad intelectual;
\end{abstract} Trastornos del desarrollo.

\section{Introduction}

People who care for a family member with an intellectual and developmental disability (IDD) may experience stress, including symptoms of anxiety and depression, and a decline in their quality of life (Dave et al., 2014; Lin et al., 2009; Seguí, Ortiz-Tallo, \& De Diego, 2008).

However, some relatives describe having a rich and full life and positive consequences due to the care experience (Dykens, 2006). One resilience factor that has gained importance in recent years has been the trait of mindfulness or dispositional mindfulness (Calvete, Orue, \& Sampedro, 2017). The mindfulness construct has been described as nonevaluative, present-centered awareness that arises as a result of intentionally focusing and refocusing attention on feelings and thoughts as they occur, moment by moment (Williams, Teasdale, Segal, \& Kabat-Zinn, 2007). This trait has been associated with less anxiety and depression and with greater well-being in the general population (Baer, Smith, Hopkins, Krietemeyer, \& Toney, 2006; Brown \& Ryan, 2003) and in family caregivers of people with IDD (Jones, Hastings, Totsika, Keane, \& Rhule, 2014). In addition, mindfulnessbased interventions have shown to improve physical and

* Correspondence address [Dirección para correspondencia]

Lucía Oñate, Department of Personality, Assesment and Psychological Treatment. University of Deusto. Avenida de las Universidades 24, 48007, Bilbao, Vizcaya (Spain). E-mail: luciaonate@deusto.es
Abstract: In recent years, mindfulness-focused interventions have garnered attention in the area of family members of people with an intellectual and developmental disability (IDD). The mindfulness trait has been related to a greater well-being, lower levels of anxiety and depression and a better quality of life in this group. Therefore, developing tools that assess mindfulness is relevant. The aim of this study was to adapt the Five-Facet Mindfulness Questionnaire-Short Form (FFMQ-SF; Bohlmeijer, ten Klooster, Fledderus, Veehof, \& Baer, 2011) to Spanish caregivers of people with IDD. Two hundred sixty-five relatives of people with IDD ( $84.5 \%$ women and $15.5 \%$ men) aged between 18 and 80 years participated in the research, completing this questionnaire along with measures of psychological distress and quality of life. The results confirmed the factor structure of the FFMQ-SF, consisting of five correlated factors (Observe, Describe, Act with awareness, Nonreact to inner experience, and Nonjudge inner experience). The factors showed adequate internal consistency. In addition, significant relationships were observed between the most of the mindfulness facets and less psychological distress as well as with better quality of life. The results suggest that the FFMQ-SF can be used adequately with relatives of people with IDD

Keywords: mindfulness trait; caregivers; intellectual and developmental disabilities.

psychological health in relatives of people with IDD (Bazzano et al., 2015; Lunsky, Robinson, Reid, \& Palucka, 2015).

The rapid expansion of mindfulness-based interventions has been accompanied by the development of numerous mindfulness trait evaluation questionnaires. Thus, in the last years, more than 11 questionnaires have been created to assess the trait of mindfulness (e.g., Baer et al., 2006; Brown \& Ryan, 2003). Although several models have been proposed for mindfulness, overall, there is considerable consensus on its multidimensionality (Rau \& Williams, 2016). Baer et al. (2006) offered a multidimensional proposal that has gained great popularity in the last years. They built the Five-Facet Mindfulness Questionnaire (FFMQ), considered one of the best psychometric tools available to assess mindfulness (Park, Reilly-Spong, \& Gross, 2013).

The FFMQ was developed from the exploratory factor analysis of the items of several questionnaires to assess mindfulness, which suggested a five-factor structure. This structure was supported by a later confirmatory factor analysis (Baer et al., 2006). The five mindfulness facets were: $O b$ serve, referred to attending to or becoming aware of internal and external experiences, such as sensations, cognitions, emotions, images, sounds, and smells; Describe, or labeling internal experiences in words; Act with awareness, which includes attending to the activities that one performs at the moment and which is the opposite of carrying out activities automatically; Nonjudge inner experience, which refers to taking a nonevaluative perspective of thoughts and feelings; and Nonreact 
to inner experience, referring to the tendency to let thoughts and feelings come and go without being carried away by them. These five scales were created from the selection of the seven or eight items with the highest factor-loadings on their respective factors (and low loadings on the other factors), resulting in a 39-item questionnaire. These facets showed adequate internal consistency, with alphas ranging from .75 to .91 (Baer et al., 2006).

The FFMQ has been shown to correlate positively with other measures, such as emotional regulation and openness to experience, and negatively with emotional stress (Baer et al., 2006; Boden \& Thompson, 2015; Cebolla et al., 2012). However, the Observe factor has shown contradictory results in non-meditators because it is not always associated with fewer psychological symptoms or has even been associated with more symptoms (Baer et al., 2008; de Bruin, Topper, Muskens, Bögels, \& Kamphuis, 2012).

In addition, the FFMQ is sensitive to the changes experienced by people who perform mindfulness-based interventions (Baer et al., 2008; de Bruin et al., 2012). The FFMQ has been adapted to different European cultures and languages such as Dutch, Belgian, French, and Spanish (Bohlmeijer, ten Klooster, Fledderus, Veehof, \& Baer, 2011; Cebolla et al, 2012; Heeren, Douilliez, Peschard, Debrauwere \& Philippot, 2011), showing good psychometric indices. It has also shown good indices in different clinical populations as well as in different chronic disorders (Cebolla et al., 2012; Bohlmeijer et al., 2011; Veehof, Ten Klooster, Taal, Westerhof, \& Bohlmeijer, 2011). Therefore, the FFMQ is considered one of the best instruments to assess dispositional mindfulness from a multifaceted perspective and with good psychometric properties (Baer et al., 2006; Park, Reilly-Spong, \& Gross, 2013), being one of the most utilized (Goldberg et al., 2016). Moreover, the FFMQ has been used in Spain in general and clinical populations (Cebolla et al., 2012; Quezada-Berumen, González-Ramírez, Cebolla, Soler, \& Garcia-Campayo, 2014) and has been utilized and adapted to Spanish adolescents showing good psychometric properties (Royuela-Colomer \& Calvete, 2016; Calvete, Gámez-Guadix \& Cortazar, 2017).

Nevertheless, the FFMQ is long (Calvete \& RoyuelaColomer, 2016; Rau \& Williams, 2016), requiring approximately 30 minutes to complete, which may be a problem when is used in combination with other measures or in different clinical populations with tendency to fatigue, boredom or who report being very busy. For this reason, Bohlmeijer et al. (2011) developed and validated an abbreviated version of the FFMQ that consisted of only 24 items (The FFMQShort Form, FFMQ-SF). This version was validated with patients with mild depressive symptoms and fibromyalgia, following the recommendations of Marsh, Ellis, Parada, Richards and Heubeck (2005) for the creation of reduced versions of questionnaires. The items that best represented the underlying factors were chosen, based on the corrected itemfactor correlation and the standardized factor loads. Moreover, the items could not correlate with other items belonging to another facet. The content of the four or five items that worked the best and the remaining items of each facet were evaluated and discussed and later confirmed in a sample of people with relevant symptomatology of anxiety and depression and in people with fibromyalgia. All the scales obtained good consistency indices (Cronbach's alphas between .75 and .87), as well as excellent convergent and divergent validity. The relationships between the different facets and other constructs such as anxiety, depression and acceptance were as good as those obtained by the complete FFMQ questionnaire. In addition, FFMQ-SF was shown to be sensitive to change after a mindfulness treatment (Bohlmeijer et al., 2011).

Since then, the FFMQ-SF has been used in clinical groups (Compen et al., 2015; Trompetter et al., 2013) and general population Newcombe \& Weaver, 2016; Pots, Trompetter, Schreurs, \& Bohlmeijer, 2016) showing adequate psychometric properties.

Despite the good psychometric properties of FFMQ-SF and its demonstrated advantages in the evaluation of clinical populations, it has not been adapted to Spanish population, either in general population or in IDD caregivers.

As mentioned, caregivers often experience considerable distress (Dave et al, 2014) and mindfulness-based interventions have shown to be beneficial in relatives of people with IDD (Bazzano et al., 2015; Lunsky et al., 2015; Singh et al., 2006). Thus, the study and assessment of dispositional mindfulness trait can generate great progress and benefits.

Therefore, the objective of this study was to examine the factor structure, the internal consistency, and the concurrent validity of the FFMQ-SF in a sample of relatives of people with IDD. It was hypothesized that the five-factor structure of the FFMQ-SF would be confirmed and that the mindfulness facets would be associated with fewer symptoms of anxiety and depression and with better indicators of quality of life. As the FFMQ-SF was administrated through different formats (online, pencil-and-paper), differences according to these formats were also examined.

\section{Method}

\section{Participants}

A total of 265 relatives participated in the research, $40 \%$ did so via pencil-and-paper and $60 \%$ online. Participants were from all Spanish Autonomous Communities except La Rioja and Ceuta (Basque Country 44.2\%, Andalusia 10.5\%, Catalonia 12.1\%, Cantabria 8.6\%, Madrid 5.9\%, Castilla y León $3.5 \%$, and others $15.2 \%$ ).

The inclusion criteria were: 1) being a relative caregiver of a person with IDD, that is, they should dedicate a minimum of 20 hours a week to the care of their relative or to related tasks; 2) living with the person with IDD or maintaining ongoing contact with him/her. We excluded those participants of whom: 1) it was suspected that they did not correctly perform the questionnaire, completing it randomly and using stereotyped response patterns; 2) they lived with the 
person with IDD but did not dedicate any time to his or her care; 3 ) the dependent person they cared for has another disability problem instead of IDD (e.g., dementia, stroke, mental health); and 4) they did not reside in Spain.

Of the participants, 224 were women $(84.5 \%)$ and 41 were men $(15.5 \%)$. The participants' mean age was 48.05 years $(S D=11.86)$, ranging from 18 to 80 . Concerning their relationship, $84.2 \%$ of the participants were parents, $13.2 \%$ were siblings, and the remaining $2.6 \%$ had another relationship, such as grandparents, uncles, and legal guardians. Regarding their educational level, $55,3 \%$ of the sample had higher studies, $26.1 \%$ had secondary studies, $15.5 \%$ had primary studies, $0.4 \%$ had not studies and $2,7 \%$ related "other conditions". Most frequent work situations of caregivers were: $47.7 \%$ actively employed, $25.8 \%$ homemakers, and $9.1 \%$ retired. In the majority of cases, the caregiver and the person with IDD lived in the same household (88.3\%). However, some caregivers reported caregiving only on certain days, for example, sharing tasks with other siblings $(3.4 \%)$, whereas other family members mentioned that, at that time, their relative did not live in the same household but that they dedicated some time to his/her supervision and care $(5.3 \%)$.

Regarding the people with disability, their average age was 20.08 years $(S D=15.18)$, with an age range between 0 and 63 years. Of them, $61.4 \%$ were men and $38.6 \%$ were women. The relatives of the people with IDD reported that in $37.1 \%$ of the cases, the their relative's intellectual disability was due to different genetic disorders: Down's Syndrome (12.7\%), Rett's Syndrome (3.5\%), Prader Willi Syndrome $(1.2 \%)$, Angelman Syndrome (0.8\%), Fragile X Syndrome $(5.8 \%)$, as well as other disorders in which intellectual disability coexists with epileptic crises, such as Dravet's Syndrome $(5 \%)$. In $27.3 \%$, the intellectual disability was due to different metabolic and acquired disorders (e.g., intrauterine infections, perinatal problems, anoxia in labor, phenylketonuria), and in $3.1 \%$, the causes were unknown. In $22.7 \%$, the cause of IDD was Autistic Spectrum Disorder, in 6.5\% it was Cerebral Palsy, and in 3.5\% it was diagnosed as Severe Learning and Language Problems.

\section{Procedure}

We contacted 20 associations of intellectual and developmental disabilities belonging to different autonomous communities in Spain. The purpose of the research was explained to the associations. The participants had the option of answering the questionnaire online, on paper and pencil, or by telephone. Subsequently, approximately another 40 associations were contacted online, of which 20 shared the publication on their social networks. In addition, research information and instructions for participation were shared on 20 websites about developmental disabilities. All participants were informed of the purpose of the research and its ethical conditions. The research was approved by the Ethics Com- mittee of the University of Deusto. Participants received no financial compensation for participating in the study.

\section{Measures}

Mindfulness - The Five-Facet Mindfulness Questionnaire - Short Form (FFMQ-SF; Bohlmeijer et al., 2011). The FFMQ-SF is a 24-item questionnaire that measures the five facets of mindfulness described above. Each subscale is made up of 5 items except for the Observe subscale, which has 4. Responses are rated on a 5 -point Likert scale ranging from 1 (never or rarely true) to 5 (very often or always true), so higher scores indicate higher mindfulness. The items of the Spanish Adaptation (Cebolla et al., 2012) were used.

Psychological Distress - The Hospital Anxiety and Depression Scale (HADS; Zigmond, \& Snaith, 1983). The Spanish version of the HADS (Tejero, Guimerá, Farré, \& Peri, 1986) was used to measure psychological distress. The HADS has two 7-item subscales that provide an anxiety coefficient and a depression coefficient. Each item has 4 response options ranging from 0 (never or not at all) to 3 (always or often), so higher scores indicate more symptoms. The alpha coefficients in this sample were $.90, .83$, and .83 for the total scale, and for anxiety and depression, respectively.

Quality of Life - The World Health Organization Quality of Life (WHO-QOL-BREF; WHO-QOL Group, 1998a; Skevington, Lotfy, \& O'Connell, 2004) was used to assess the quality of life of family members. The WHOQOL-BREF consists of 26 items that measure Physical health, Psychological health, Social relationships, and Environmental quality of life. The scale items are rated on a 5-point Likert style, ranging from 0 (no, never) to 4 (always, totally) so higher scores indicate better quality of life. The WHO-QOL-BREF is a short version of the WHO-QOL of the World Health Organization (WHO-QOL Group, 1998b). The Spanish adaptation was carried out by Espinoza, Osorio, Torrejón, LucasCarrasco and Bunout (2011) and presents acceptable psychometric properties. In this study, the total scale obtained an alpha of .93 , and its subscales obtained values ranging from .80 to .85 .

\section{Statistical Analysis}

Confirmatory factor analyses were carried out to examine the structure of the FFMQ-SF. The LISREL 9.2 (Jöreskog \& Sörbom, 2013) statistical program was used to explore the items 'normality. Univariate tests of normality were statistically significant for skewness in 9 items and for kurtosis in 21 items $(p<.05)$. In addition, tests of Multivariate Normality for Continuous Variables indicated that both skewness (z $=88.21, p<.001)$ and kurtosis $(z=23.25, p<.001)$ values were statistically significant, indicating that the multivariate distribution was not normal. As the items did not follow a normal multivariate distribution, the robust maximum likelihood (RML) method with LISREL 9.2 was used. This method requires estimating both the covariance matrix and the 
asymptotic covariance matrix and uses the Chi-Square scaled Satorra-Bentler value (S-B $\chi 2$; Chou, Bentler, \& Satorra, 1991). To evaluate the goodness of fit of the models, the mean square error of approximation error (RMSEA), the comparative adjustment index (CFI), and the non-normative adjustment index (NNFI) were used. According to several authors (Hu \& Bentler, 1999), values of IFC and NNFI greater than .90 and RMSEA values less than .06 reflect a good fit, whereas RMSEA values between .06 and .08 show an adequate fit.

The SPSS 23 statistical program was used to study the internal consistency of each subscale using Cronbach's Alpha. The Discrimination Index (DI) of the items was calculated by partial correlation eliminating the influence of the item in each subscale of the test. The Kolmogorov-Smirnov Lilliefors test was used to explore the normality of the distributions in the different scales and subscales. The concurrent validity of criterion was assessed by means of correlations $(r$ Spearman) with the other constructs (i.e., anxiety, depression, and quality of life). Finally, as participants could complete measures both online and pencil and paper, we examined potential differences in the scores and reliability of the measure depending on the format used. As the format of responding could have been influenced by the profile of the participants, we examined differences between them by means of the U Mann-Whitney and Chi Square tests.

\section{Results}

\section{Factor Structure}

The hypothetical model consisted of five correlated latent variables: 1) Describe (5 items), 2) Act with awareness (5 items), 3) Nonjudge (5 items), 4) NonReact (5 items), and 5) Observe (4 items). The measurement errors of the items were not allowed to correlate. The solution showed adequate fit indices, Satorra-Bentler $\chi^{2}(242, n=265)=742, p<.001$; RMSEA $=.08,90 \%$ CI $[.07, .09]$, CFI $=.93$, NNFI $=.92$. All the factor loadings were statistically different from zero and higher than .40 (values between .44 and .95 ) except for items 8 and 11, which were somewhat lower (.34 and .28, respectively).

Table 1. Item Factorial Loading and Discrimination Index.

\begin{tabular}{|c|c|c|c|c|c|c|c|}
\hline & & DS & NR & NJ & AA & OBS & DI \\
\hline FFMQ1 & Soy bueno en encontrar palabras para describir mis sentimientos. & .87 & & & & & .61 \\
\hline FFMQ2 & Puedo poner fácilmente en palabras mis creencias, opiniones y expectativas. & .93 & & & & & .64 \\
\hline /FFMQ5 & Me digo a mi mismo que no me debería estar sintiendo como me estoy sintiendo. & .44 & & & & & .47 \\
\hline /FFMQ11 & $\begin{array}{l}\text { Cuando tengo una sensación en mi cuerpo, me es difícil describirla pues no encuentro las } \\
\text { palabras adecuadas. }\end{array}$ & .28 & & & & & .30 \\
\hline FFMQ16 & $\begin{array}{l}\text { Incluso cuando me siento tremendamente alterado, soy capaz de encontrar la manera de } \\
\text { expresarlo. }\end{array}$ & .71 & & & & & .59 \\
\hline FFMQ3 & Observo mis sentimientos sin perderme en ellos. & & .72 & & & & .55 \\
\hline FFMQ9 & $\begin{array}{l}\text { Cuando tengo pensamientos o imágenes mentales negativas, me detengo y tomo conciencia } \\
\text { de ellos sin dejar que me afecten. }\end{array}$ & & .71 & & & & .56 \\
\hline FFMQ13 & Cuando tengo pensamientos o imágenes mentales negativas, me tranquilizo rápido. & & .77 & & & & .63 \\
\hline FFMQ18 & $\begin{array}{l}\text { Cuando tengo pensamientos o imágenes mentales negativas, soy capaz de observarlas sin } \\
\text { reaccionar. }\end{array}$ & & .46 & & & & .43 \\
\hline FFMQ21 & $\begin{array}{l}\text { Cuando tengo pensamientos o imágenes mentales negativas, puedo reconocerlas como tales } \\
\text { y dejarlas ir. }\end{array}$ & & .71 & & & & .59 \\
\hline /FFMQ4 & Me digo a mi mismo que no me debería estar sintiendo como me estoy sintiendo. & & & .46 & & & .37 \\
\hline /FFMQ7 & Hago juicios sobre si mis pensamientos son malos o buenos. & & & .71 & & & .51 \\
\hline /FFMQ14 & Me digo a mi mismo que no debería estar pensando como estoy pensando. & & & .69 & & & .56 \\
\hline /FFMQ19 & Pienso que algunas de mis emociones son malas o inapropiadas, y que no debería sentirlas. & & & .52 & & & .38 \\
\hline /FFMQ24 & Me critico cuando tengo ideas absurdas. & & & .65 & & & .50 \\
\hline /FFMQ8 & Se me hace difícil mantenerme enfocado en lo que ocurre en el presente. & & & & .34 & & .29 \\
\hline /FFMQ12 & Parece que actúo en "piloto automático", sin pensar en lo que estoy haciendo. & & & & .68 & & .59 \\
\hline /FFMQ17 & Voy de una actividad a otra sin prestar atención a cada una de ellas. & & & & .73 & & .65 \\
\hline /FFMQ22 & Hago deberes o tareas automáticamente sin ser consciente de lo que hago. & & & & .93 & & .71 \\
\hline /FFMQ23 & Me encuentro a mí mismo haciendo cosas sin prestarles atención. & & & & .95 & & .74 \\
\hline FFMQ6 & Presto atención a sensaciones, como el viento en mi cabello o el sol sobre mi rostro. & & & & & .76 & .64 \\
\hline FFMQ10 & $\begin{array}{l}\text { Presto atención a sonidos, como al tic tac del reloj, el cantar de los pájaros o el ruido de los } \\
\text { coches. }\end{array}$ & & & & & .76 & .65 \\
\hline FFMQ15 & Percibo los olores y aromas de las cosas. & & & & & .71 & .58 \\
\hline FFMQ20 & $\begin{array}{l}\text { Me fijo en elementos visuales, en el arte o en la naturaleza como colores, formas, texturas, } \\
\text { patrones de luz y sombra. }\end{array}$ & & & & & .83 & .69 \\
\hline
\end{tabular}

Note. $\mathrm{OB}=$ Observe; $\mathrm{DS}=$ Describe; $\mathrm{AA}=$ Act with awareness; $\mathrm{NJ}=$ Nonjudge; $\mathrm{NR}=$ Nonreact; $\mathrm{DI}=$ Discrimination Index. 
We also compared the previous model with an orthogonal structure in which all latent variables were specified as uncorrelated. This model obtained considerably lower fit indices, Satorra-Bentler $\chi^{2}(252, n=265)=1300, p<.001$; RMSEA $=.09,90 \%$ CI $[.92, .10]$, CFI $=.90$, NNFI $=0.89$. The comparison using the corrected chi-square difference test (Crawford \& Henry, 2003) indicated a statistically significant change in Satorra-Bentler $\chi^{2}, \Delta \chi^{2}(10, n=265)=132, p$ $<.001$. Finally, we estimated a single-factor model in which all items were explained by a single trait of mindfulness. This model had a poor fit, Satorra-Bentler $\chi^{2}(252, n=252)=$ $2208, p<.001$; RMSEA $=.18,90 \%$ CI $[.17, .18]$, CFI $=.64$, NNFI $=.61$, and also significantly increased the SatorraBentler $\chi^{2}$ value, $\Delta \chi^{2}(10, n=265)=687, p<.001$. Therefore, the model of five correlated facets was preferable. The discrimination index of the items were generally adequate (values higher than 0.3 ) except in item 8 (.23 value).

\section{Internal Consistency estimation}

The analysis of the internal consistency of each dimension was estimated by the Cronbach's alpha coefficients. The alpha coefficients were $.82, .75, .80, .70$, and .78 for Observe, Describe, Act with Awareness, Nonjudge, and Nonreact, respectively.

\section{Correlations between facets}

The Kolmogorov-Smirnov Lilliefors test showed that the Mindfulness facets did not fit a normal distribution $(p<.05)$. Thus, non-parametric analyses were used to study associations between facets. Table 2 shows the Spearman correlations between the five mindfulness facets. Most of them are significant and moderate. Their values ranged from 25 to 41 .

Table 2. Mindfulness facets' Means, Standard Deviations, and Alpha Coefficients.

\begin{tabular}{lccccccccc}
\hline & $\begin{array}{c}\text { A } \\
\text { total }\end{array}$ & $\begin{array}{c}\alpha \\
\text { pap. }\end{array}$ & $\begin{array}{c}\alpha \\
\text { onl. }\end{array}$ & $M$ & $S D$ & OB & DS & AA & NJ \\
\hline OB & .82 & .77 & .83 & 12.31 & 4.51 & & & \\
DS & .75 & .72 & .77 & 17.49 & 4.06 & $.26^{* *}$ & & & \\
AA & .80 & .82 & .79 & 17.31 & 4.60 & .08 & $.25^{* *}$ & & \\
NJ & .71 & .73 & .69 & 15.32 & 3.97 & $-.25^{* *}$ & .01 & $.36^{* *}$ & \\
NR & .78 & .67 & .81 & 13.99 & 4.14 & $.34^{* *}$ & $.41^{* *}$ & $.22^{* *}$ & -.10 \\
\hline NR
\end{tabular}

Note. pap. $=$ paper; onl. $=$ online; $\mathrm{OB}=$ Observe; $\mathrm{DS}=$ Describe; $\mathrm{AA}=$ Act with awareness; $\mathrm{NJ}=$ Nonjudge; $\mathrm{NR}=$ Nonreact; Total $=$ Mindfulness to-tal score. $* p<.05 . * * p<.01$.

\section{Correlations with other Constructs- Concurrent Va- lidity}

Table 3 displays the correlation coefficients between the mindfulness facets and measures of psychological distress and quality of life. Overall, all facets were significantly associated with fewer symptoms of anxiety and depression, except for the correlation between Nonjudge and depression, which was not statistically significant. Likewise, the mindfulness facets were associated with better quality of life in all cases except for Nonjudge, which was not significantly associated with environmental quality of life, and Observe, which was not significantly associated with physical quality of life. In general, the highest correlations were observed for Nonreact and Act with awareness.

Table 3. Correlations between Mindfulness facets (FFMQ-SF) and other Constructs.

\begin{tabular}{|c|c|c|c|c|c|c|c|c|}
\hline & HADS Total & HADSAnx. & $\begin{array}{c}\text { HADS } \\
\text { Dep. }\end{array}$ & QL & $\begin{array}{l}\text { Ph. } \\
\text { QL }\end{array}$ & $\begin{array}{l}\text { Ps. } \\
\text { QL }\end{array}$ & $\begin{array}{l}\text { Soc. } \\
\text { QL }\end{array}$ & $\begin{array}{c}\text { Env. } \\
\text { QL }\end{array}$ \\
\hline$\overline{\mathrm{OB}}$ & $-.23 * *$ & $-16^{* *}$ & $-.26^{* *}$ & $.19 * *$ & .09 & $.21 * *$ & $.20 * *$ & $.18^{* *}$ \\
\hline DS & $-.20 * *$ & $-.17 * *$ & $-.21 * *$ & $.29 * *$ & $.21 * *$ & $.31 * *$ & $.25^{* *}$ & $.24 * *$ \\
\hline AA & $-.45^{* *}$ & $-.40 * *$ & $-.43 * *$ & $.40^{* *}$ & $.35^{* *}$ & $.43^{* *}$ & $.39 * *$ & $.21 * *$ \\
\hline NJ & $-.19 * *$ & $-.23 * *$ & -.11 & $.16^{*}$ & $.14^{*}$ & $.17 * *$ & $.13^{*}$ & .06 \\
\hline NR & $-.44 * *$ & $-.40 * *$ & $-.41 * *$ & $.43^{* *}$ & $.29 * *$ & $.50^{* *}$ & $.41^{* *}$ & $.28^{* *}$ \\
\hline
\end{tabular}

Note. HADS = Hospital Anxiety and Depression Scale; Anx = Anxiety; Dep=Depression; QL=Quality of life (WHO-QOL-BREF); Ph. QL= Physical health quality of life; Ps. QL=Psychological health quality of life; Soc. QL= Social relationships quality of life; Env. QL= Environmental quality of life. $* p<.05 . * * p<.01$.

\section{Differences between Formats}

The U Mann-Whitney test was used for the study of differences according to the format (online/paper) due to the non-normality of the facets. The effect size was calculated using the equation $r=z / \sqrt{ } N$ (Rosenthal, 1991; Field, 2009). As Table 4 shows, in most cases, there were not significant differences in the facets according to the format (online and paper-and-pencil). Nevertheless, two facets obtained significantly higher scores on paper: Observe and Nonreact. However, the effect sizes were small, with values lower of 0.3 (Cohen, 1988). Alpha coefficients for the online format were slightly higher for the Observe, Nonreact, and Describe subscales. On another hand, alpha coefficients were higher in paper format for Act with awareness and Nonjudge subscales (see Table 2). 
Table 4. Differences between Formats according to Format (pencil \& paper / online).

\begin{tabular}{lccccc}
\hline & OB & DS & AA & NJ & NR \\
\hline$U$ & 6736.50 & 7544.00 & 7425.50 & 7978.50 & 7017.00 \\
$Z$ & -2.77 & -1.45 & -1.64 & -.74 & -2.31 \\
$P$ & $<.05$ & .15 & .10 & .46 & $<.05$ \\
$\mathrm{R}$ & -.17 & -.08 & -.10 & -.05 & -.14 \\
\hline Note. $U=$ Mann-Whitney statistic value; $z=$ Standardized score of normal distribution; $r=$ effect size & &
\end{tabular}

The sociodemographic profiles of the participants of each format were compared. Table 5 indicates that there are some significant differences in the sociodemographic characteristics of the participants who used each format. In general, people who used paper and pencil format had older age, lower level of education, they were retirees and supported adults with IDD, especially with organic disorders. On the other hand, people who used online format were younger people, with higher level of education, workers, and who provided support to children with IDD, with Autistic and Learning disorders.

$\underline{\text { Table 5. Differences between Formats in Sociodemographics. }}$

\begin{tabular}{|c|c|c|c|c|c|c|c|}
\hline & & & $\begin{array}{l}\text { Online } \\
159\end{array}$ & $\begin{array}{c}\text { Pencil \& Paper } \\
106\end{array}$ & & & \\
\hline Participant's Age* & & & $M d n=42$ & $M d n=55.5$ & \multirow{2}{*}{\multicolumn{3}{|c|}{$\begin{array}{c}U=3275.50, z=-8.43, p .<.001, r=-.51 \\
U=6713.50, z=-.61, p=.54, r=-.03\end{array}$}} \\
\hline \multirow[t]{2}{*}{ N. hours } & & & $M d n=35$ & $M d n=32$ & & & \\
\hline & & $N$ & & & & $C C$ & $V$ \\
\hline \multirow[t]{2}{*}{ Sex* } & Female & 224 & $62.9 \%$ & $37.1 \%$ & $X^{2}(1)=5.24$ & \multirow{2}{*}{.14} & \multirow{2}{*}{.14} \\
\hline & Male & 41 & $43.9 \%$ & $56.1 \%$ & $p<.05$ & & \\
\hline \multirow[t]{3}{*}{ Relationship* } & Parents & 223 & $63.7 \%$ & $36.3 \%$ & & \multirow{3}{*}{.19} & \multirow{3}{*}{.20} \\
\hline & Siblings & 35 & $45.7 \%$ & $54.3 \%$ & $X^{2}(2)=10.33$ & & \\
\hline & Other & 7 & $14.3 \%$ & $85.7 \%$ & $p<.03$ & & \\
\hline \multirow[t]{2}{*}{ Partnership* } & Without & 74 & $47.3 \%$ & $52.7 \%$ & $X^{2}(1)=6.74$ & \multirow{2}{*}{.16} & \multirow{2}{*}{.16} \\
\hline & With & 190 & $64.7 \%$ & $35.3 \%$ & $p<.05$ & & \\
\hline \multirow[t]{6}{*}{ Work* } & Active & 126 & $70.6 \%$ & $29.4 \%$ & & \multirow{6}{*}{.28} & \multirow{6}{*}{.29} \\
\hline & Homemakers & 68 & $50 \%$ & $50 \%$ & & & \\
\hline & Looking for & 23 & $47.8 \%$ & $52.2 \%$ & $X^{2}(5)=22.04$ & & \\
\hline & Retired & 24 & $29.2 \%$ & $70.8 \%$ & $p \leq .001$ & & \\
\hline & Student & 5 & $60 \%$ & $40 \%$ & & & \\
\hline & Other & 18 & $77.8 \%$ & $22.2 \%$ & & & \\
\hline \multirow[t]{4}{*}{ Household* } & Always & 234 & $60.7 \%$ & $39.3 \%$ & & \multirow{4}{*}{.15} & \multirow{4}{*}{.15} \\
\hline & Certain days & 9 & $22.2 \%$ & $77.8 \%$ & $X^{2}(3)=6.26$ & & \\
\hline & Not & 14 & $64.3 \%$ & $35.7 \%$ & $p=.1$ & & \\
\hline & Other & 8 & $75 \%$ & $25 \%$ & & & \\
\hline \multirow[t]{5}{*}{ Studies* } & No studies & 1 & $0 \%$ & $100 \%$ & & \multirow{5}{*}{.30} & \multirow{5}{*}{.32} \\
\hline & Primary studies & 41 & $29.3 \%$ & $70.7 \%$ & $X^{2}(4)=26.63$ & & \\
\hline & Second studies & 69 & $62.3 \%$ & $37.7 \%$ & $p<.001$ & & \\
\hline & Higher studies & 146 & $69.9 \%$ & $30.1 \%$ & & & \\
\hline & Other & 7 & $28.6 \%$ & $71.4 \%$ & & & \\
\hline \multirow[t]{3}{*}{ IDD person's Age* } & Child ( $0-18$ years) & 149 & $79.9 \%$ & $20.1 \%$ & $X^{2}(2)=55.12$ & \multirow{3}{*}{.42} & \multirow{3}{*}{.46} \\
\hline & Young (18-30 years) & 62 & $33.9 \%$ & $66.1 \%$ & $p<.001$ & & \\
\hline & Adult $(+30)$ & 53 & $35.8 \%$ & $64.2 \%$ & & & \\
\hline \multirow[t]{6}{*}{ IDD cause* } & Genétic & 96 & $66.7 \%$ & $33.3 \%$ & & \multirow{6}{*}{.41} & \multirow{6}{*}{.45} \\
\hline & Organic & 71 & $28.2 \%$ & $71.8 \%$ & $X^{2}(5)=52.72$ & & \\
\hline & $\mathrm{CP}$ & 17 & $58.8 \%$ & $41.2 \%$ & $p<.001$ & & \\
\hline & Unknown & 8 & $62.5 \%$ & $37.5 \%$ & & & \\
\hline & ASD & 59 & $88.1 \%$ & $11.9 \%$ & & & \\
\hline & SLD & 9 & $77.8 \%$ & $22.2 \%$ & & & \\
\hline
\end{tabular}

Note: $\mathrm{CC}=$ Contingency Coefficient; $\mathrm{V}=$ Crammer's V; CP = Cerebral Palsy; ASD = Autistic Spectrum Disorder; SLD= Severe Learning Disabilities; *significant differences

\section{Discussion}

The assessment of dispositional mindfulness in caregivers of a person with IDD is important, as mindfulness has been found to act as a resilience fact in this population (Jones, et al., 2014). The short version of the FFMQ (Bohlmeijer et al., 2011) offers advantages over the full version as it considerably reduces application time. Thus, the aim of this study was to examine some psychometric properties of the FFMQ-SF 
in a Spanish sample, more specifically, in relatives who care for a person with IDD. The results confirmed the hypothesis concerning the existence of the five facets of mindfulness found previously in the long version (Baer et al., 2006) and the short version (Bohlmeijer et al., 2011). The factor loadings of the items were adequate in most cases. Although some of the alphas were slightly lower than those obtained in the original short version of the FFMQ (Bohlmeijer et al., 2011), the FFMQ-SF displays adequate internal consistency in our sample, as in other studies (Compen et al., 2015; Eisenlohr-Moul, Peters, Chamberlain, \& Rodriguez, 2015; Trompetter et al., 2013).

Most of the correlations between mindfulness facets were moderate and statistically significant. However, correlations were no significant between Observe and Act with awareness, Nonjudge and Nonreact, and Nonjudge and Describe facets. The correlation between Nonjudge and Describe was also not significant in the original FFMQ-SF validation (Bohlmeijer et al., 2011). In addition, Observe was negatively associated with Nonjudge. This relation has already been found in previous studies (Sugiura, Sato, Ito \& Murakami, 2012). As mentioned, it is common to find controversial results for the Observe facet in non-meditating samples (de Bruin et al., 2012).

Consistent with the second hypothesis of the study, the mindfulness facets correlated negatively with less anxiety and depression and positively with quality of life. This finding is consistent with previous studies of the role of mindfulness in relatives of people with IDD (Jones et al., 2014; Lloyd \& Hastings, 2008). Act with awareness and Nonreact were the facets with higher association values. Therefore, we can say that they seem the most beneficial to family caregivers of people with IDD. These facets have been considered to provide the strongest theoretical and empirical association with the construct mindfulness (Rau \& Williams, 2015) and have been highlighted by their adaptive role in other Spanish samples (Royuela-Colomer \& Calvete, 2016).

In contrast with findings of other studies (Baer et al., 2008; Royuela-Colomer \& Calvete, 2016), the Observe facet was related to lower psychological distress and better quality of life in the majority of cases. Thus, Observe behaved similarly as in people who habitually meditate (Baer et al., 2008; de Bruin et al., 2012; Gu et al., 2016). For this reason, it

\section{References}

Baer, R. A., Smith, G. T., Hopkins, J., Krietemeyer, J., \& Toney, L. (2006). Using self-report assessment methods to explore facets of mindfulness. Assessment, 13(1), 27-45. doi:10.1177/1073191105283504

Baer, R. A., Smith, G. T., Lykins, E., Button, D., Krietemeyer, J., Sauer, S., ... \& Williams, J. M. G. (2008). Construct validity of the Five-Facet Mindfulness Questionnaire in meditating and nonmeditating samples. Assessment, 15(3), 329-342. doi:10.1177/1073191107313003

Bazzano, A., Wolfe, C., Zylowska, L., Wang, S., Schuster, E., Barrett, C., \& Lehrer, D. (2015). Mindfulness-based stress reduction (MBSR) for parents and caregivers of individuals with developmental disabilities: A community-based approach. Journal of Child and Family Studies, 24(2), 298-308. doi:10.1007/s10826-013-9836-9 would be interesting to continue studying in more depth the functioning of this facet in this sample.

No greater differences were found between mindfulness trait results obtained online and on paper, except for the Observe and Nonreact facets, being the effect sizes small. These differences could be due to the differences between the profiles of participants (e.g., age, education, etc.) who accessed each format. It might be interesting to control this aspect in future research.

This research is not without limitations. The FFMQ-SF is a self-report questionnaire, and the participants' sincerity is essential to the reliability of the results obtained. Moreover, although this study explored several psychometric properties (factorial validity, concurrent validity, internal consistency), other psychometric properties, such as test-retest and predictive validity, should be examined. The present investigation consisted of a cross-sectional study. However, longitudinal studies are necessary to examine the predictive validity and test-retest reliability of the FFMQ-SF. Finally, in the present study, the percentage of male participants was small. Future research should examine gender differences in the role of mindfulness in the distress of family caregivers.

In conclusion, the data obtained in this sample of Spanish relatives who care for a person with IDD confirm the adequacy of FFMQ-SF. The structure of the FFMQ-SF was confirmed, showing some good psychometric properties. Thus, FFMQ-SF is an adequate questionnaire to assess the facets of the mindfulness trait, which may be useful in the clinical area and in research. Moreover, the FFMQ-SF may be beneficial to be used together with other assessment instruments or in certain groups where it may be advantageous to use shorter versions of the mindfulness measure. Findings indicate the positive role of dispositional mindfulness for mental health, being the Act with Awareness and Nonreact facets especially beneficial in familiar caregivers of people with IDD.

Acknowledgements: This research was funded by the Basque Country Government (Refs. PRE_2016_2_0004 and Ref. IT98216). The authors thank the families and associations that gave up their time to take part in this study (Gorabide, Gaude, Amica, Asbibe, Adicas \& others).

Boden, M. T., \& Thompson, R. J. (2015). Facets of emotional awareness and associations with emotion regulation and depression. Emotion, 15(3), 399-410. doi:http://dx.doi.org/10.1037/emo0000057

Bohlmeijer, E., ten Klooster, P. M., Fledderus, M., Veehof, M., \& Baer, R. (2011). Psychometric properties of the Five-Facet Mindfulness Questionnaire in depressed adults and development of a short form. Assessment, 18(3), 308-320. doi:10.1177/1073191111408231

Brown, K. W., \& Ryan, R. M. (2003). The benefits of being present: Mindfulness and its role in psychological well-being. Journal of Personality and Social Psychology, 84(4), 822-848. doi:10.1037/0022-3514.84.4.822 
Calvete, E., Gámez-Guadix, M., \& Cortazar, N. (2017). Mindfulness facets and problematic Internet use: A six-month longitudinal study. Addictive Behaviors, 72, 57-63.doi: 10.1016/j.addbeh.2017.03.018

Calvete, E., Orue, I., \& Sampedro, A. (2017). Does the acting with awareness trait of mindfulness buffer the predictive association between stressors and psychological symptoms in adolescents? Personality and Individual Differences, 105, 158-163. doi:10.1016/j.paid.2016.09.055

Calvete, E., \& Royuela- Colomer, E. (2016). Measurement of dispositional mindfulness in children and adolescents: A review of available selfreport measures in Spanish. Mindfulness \& Compassion, 1, 58-87. doi:10.1016/j.mincom.2016.11.001

Cebolla, A., García-Palacios, A., Soler, J., Guillen, V., Baños, R., \& Botella, C. (2012). Psychometric properties of the Spanish validation of the Five-Facet Mindfulness Questionnaire (FFMQ). The European Journal of Psychiatry, 26(2), 118-126. doi:10.4321/S0213-61632012000200005

Chou, C. P., Bentler, P. M., \& Satorra, A. (1991). Scaled test statistics and robust standard errors for non-normal data in covariance structure analysis: a Monte Carlo study. British Journal of Mathematical and Statistical Psychology, 44(2), 347-357. doi:10.1111/j.2044-8317.1991.tb00966.x

Cohen, J. (1988). Statistical power analysis for the behavioral sciences (2nd ed.). Hillsdale, NJ: Lawrence Earlbaum Associates.

Compen, F. R., Bisseling, E. M., Van der Lee, M. L., Adang, E. M. M., Donders, A. R. T., \& Speckens, A. E. M. (2015). Study protocol of a multicenter randomized controlled trial comparing the effectiveness of group and individual internet-based mindfulness-based cognitive therapy with treatment as usual in reducing psychological distress in cancer patients: The BeMind study. BMC Psychology, 3(1), 27. doi:10.1186/s40359-015-0084-1

Crawford, J. R. \& Henry, J. D. (2003). The Depression Anxiety Stress Scales: Normative data and latent structure in a large non-clinical sample. British Journal of Clinical Psychology, 42, 111-131. doi:10.1348/014466503321903544

Dave, D., Mittal, S., Tiwari, D., Parmar, M. C., Gedan, S., \& Patel, V. (2014). Study of anxiety and depression in caregivers of intellectually disabled children. Journal of Research in Medical and Dental Science, 2(1), 813. doi: $10.5455 /$ jrmds. 2014212

de Bruin, E. I., Topper, M., Muskens, J. G., Bögels, S. M., \& Kamphuis, J. H. (2012). Psychometric properties of the Five-Facet Mindfulness Questionnaire (FFMQ) in a meditating and a non-meditating sample. Assessment, 19(2), 187-197. doi:10.1177/1073191112446654

Dykens, E. M. (2006). Toward a positive psychology of mental retardation. American Journal of Orthopsychiatry, 76(2), 185-193. doi:10.1037/00029432.76.2.185

Eisenlohr-Moul, T. A., Peters, J. R., Chamberlain, K. D., \& Rodriguez, M. A. (2016). Weekly fluctuations in nonjudging predict borderline personality disorder feature expression in women. Journal of Psychopathology and Behavioral Assessment, 38(1), 149-157. doi:10.1007/s10862-015-9505$\mathrm{y}$

Espinoza, I., Osorio, P., Torrejón, M. J., Lucas-Carrasco, R., \& Bunout, D. (2011). Validación del Cuestionario de Calidad de Vida (WHOQOLBREF) en adultos mayores chilenos. Revista Médica de Chile, 139(5), 579_ 586. doi: 10.4067/S0034-98872011000500003

Field, A. P. (2009). Discovering statistics using SPSS (4th. Edition). London, England: SAGE.

Goldberg, S. B., Wielgosz, J., Dahl, C., Schuyler, B., MacCoon, D. S. Rosenkranz, M., ... \& Davidson, R. J. (2016). Does the Five Facet Mindfulness Questionnaire measure what we think it does? Construct validity evidence from an active controlled randomized clinical trial. Psychological assessment, 28(8), 1009-1014. doi:10.1037/pas0000233

Gu, J., Strauss, C., Crane, C., Barnhofer, T., Karl, A., Cavanagh, K., \& Kuyken, W. (2016). Examining the factor structure of the 39-item and 15-item versions of the Five-Facet Mindfulness Questionnaire before and after mindfulness-based cognitive therapy for people with recurrent depression. Psychological Assessment, 28(7), 791-802. doi: $10.1037 /$ pas0000263

Heeren, A., Douilliez, C., Peschard, V., Debrauwere, L., \& Philippot, P. (2011). Cross-cultural validity of the Five-Facet Mindfulness Questionnaire: Adaptation and validation in a French-speaking sample. Revue
Européenne de Psychologie Appliquée / European Review of Applied Psychology, 61(3), 147-151. doi:10.1016/j.erap.2011.02.001

Hu, L. T. \& Bentler, P.M. (1999). Cutoff criteria for fit indexes in covariance structure analysis: Conventional criteria versus new alternatives. Structural Equation Modeling: A Multidisciplinary Journal, 6(1), 1-55. doi: 10.1080/10705519909540118

Jones, L., Hastings, R. P., Totsika, V., Keane, L., \& Rhule, N. (2014). Child behavior problems and parental well-being in families of children with autism: The mediating role of mindfulness and acceptance. American Journal on Intellectual and Developmental Disabilities, 119(2), 171-185. doi:10.1352/1944-7558-119.2.171. doi:10.1093/clipsy/bpg016

Jöreskog, K. G., \& Sörbom, D. (2013). LISREL 9.10. Lincolnwood, IL: Scientific Software International.

Lin, J. D., Hu, J., Yen, C. F., Hsu, S. W., Lin, L. P., Loh, C. H., ... \& Wu, J. L. (2009). Quality of life in caregivers of children and adolescents with intellectual disabilities: use of WHOQOL-BREF survey. Research in Developmental Disabilities, 30(6), 1448-1458. doi:10.1016/j.ridd.2009.07.005

Lloyd, T., \& Hastings, R. P. (2008). Psychological variables as correlates of adjustment in mothers of children with intellectual disabilities: Cross-sectional and longitudinal relationships. Journal of Intellectual Disability Research, 52(1), 37-48.doi:10.1111/j.1365-2788.2007.00974.x

Lunsky, Y., Robinson, S., Reid, M., \& Palucka, A. (2015). Development of a mindfulness-based coping with stress group for parents of adolescents and adults with developmental disabilities. Mindfulness, 6(6), 1335-1344. doi:10.1007/s12671-015-0404-9

Marsh, H. W., Ellis, L. A., Parada, R. H., Richards, G., \& Heubeck, B. G. (2005). A short version of the Self-Description Questionnaire II: Operationalizing criteria for short-form evaluation with new applications of confirmatory factor analyses. Psychological Assessment, 17(1), 81-102. doi:10.1037/1040-3590.17.1.81

Newcombe, B. C., \& Weaver, A. D. (2016). Mindfulness, cognitive distraction, and sexual well-being in women. The Canadian Journal of Human Sexuality, 25(2), 99-108. doi: 10.3138/cjhs.252-A3

Park, T., Reilly-Spong, M., \& Gross, C. R. (2013). Mindfulness: A systematic review of instruments to measure an emergent patient-reported outcome (PRO). Quality of Life Research, 22(10), 2639-2659. doi:10.1007/s11136-013-0395-8

Pots, W. T., Trompetter, H. R., Schreurs, K. M., \& Bohlmeijer, E. T. (2016). How and for whom does web-based acceptance and commitment therapy work? Mediation and moderation analyses of web-based ACT for depressive symptoms. BMC Psychiatry, 16(1), 158. doi:10.1186/s12888-016-0841-6

Quezada-Berumen, L.; González-Ramírez, M.T.; Cebolla, A.; Soler, J., \& Garcia-Campayo, J. (2014). Conciencia corporal y mindfulness: Validación de la versión española de la escala de conexión corporal (SBC). Actas Españolas de Psiquiatría, 42(2), 57-67.

Rau, H. K., \& Williams, P. G. (2016). Dispositional mindfulness: A critical review of construct validation research. Personality and Individual Differences, 93, 32-43. doi:10.1016/j.paid.2015.09.035

Rosenthal, R. (1991). Meta - analytic procedures for social research (2nd ed.). Newbury Park, CA: Sage.

Royuela-Colomer, E., \& Calvete, E. (2016). Mindfulness facets and depression in adolescents: Rumination as a mediator. Mindfulness, 7(5), 1092 1102. doi:10.1007/s12671-016-0547-3

Seguí, J. D., Ortiz-Tallo, M., \& De Diego, Y. (2008). Factores asociados al estrés del cuidador primario de niños con autismo: Sobrecarga, psicopatología y estado de salud. Anales de Psicología, 1(2), 100-105.

Singh, N. N., Lancioni, G. E., Winton, A. S., Fisher, B. C., Wahler, R. G. Mcaleavey, K., ... \& Sabaawi, M. (2006). Mindful parenting decreases aggression, noncompliance, and self-injury in children with autism. Journal of Emotional and Behavioral Disorders, 14(3), 169177.doi: $10.1177 / 10634266060140030401$

Skevington, S. M., Lotfy, M., \& O'Connell, K. A. (2004). The World Health Organization's WHOQOL-BREF quality of life assessment: Psychometric properties and results of the international field trial. A report from the WHOQOL group. Quality of Life Research, 13(2), 299-310. doi: 10.1023/B:QURE.0000018486.91360.00 
Sugiura, Y., Sato, A., Ito, Y., \& Murakami, H. (2012). Development and Validation of Japanese Version of the Five Facets Mindfulness Questionnaire. Mindfulness,3, 85-94. doi: 10.1007/s12671-011-0082-1

Tejero, A., Guimerá, E. M., Farré, J. M., \& Peri, J. M. (1986). Clinical use of HADS in psychiatric samples: A sensitivity, reliability and validity study. Revista Departamento Psiquiatría Facultad de Medicina de Barcelona, 13, 233-238.

Trompetter, H. R., Ten Klooster, P. M., Schreurs, K. M., Fledderus, M., Westerhof, G. J., \& Bohlmeijer, E. T. (2013). Measuring values and committed action with the Engaged Living Scale (ELS): Psychometric evaluation in a nonclinical sample and a chronic pain sample. Psychological Assessment, 25(4), 1235-1246. doi:10.1037/a0033813

Veehof, M. M., Ten Klooster, P. M., Taal, E., Westerhof, G. J., \& Bohlmeijer, E. T. (2011). Psychometric properties of the Dutch FiveFacet Mindfulness Questionnaire (FFMQ) in patients with fibromyal- gia. Clinical Rheumatology, 30(8), 1045-1054. doi:10.1007/s10067-0111690-9

Williams, M., Teasdale, J., Segal A., \& Kabat-Zinn J. (2007). The mindful way through depression. New York: Guilford Press.

WHOQOL Group (1998a). Development of the World Health Organization WHOQOL-BREF quality of life assessment. The WHOQOL Group. Psychological Medicine, 28, 551-558.

WHOQOL Group (1998b). The World Health Organization Quality of Life Assessment (WHOQOL): Development and general psychometric properties. Social Science and Medicine, 46, 1569-1585

Zigmond, A. S., \& Snaith, R. P. (1983). The Hospital Anxiety and Depression Scale. Acta Psychiatrica Scandinavica,67(6), 361-370. doi: 10.1111/j.1600-0447.1983.tb09716.x

(Article received: 22-05-2017; revised: 15-09-2017; accepted: 18-10-2017 